\title{
Vulnerable Islands: Climate Change, Tectonic Change, and Changing Livelihoods in the Western Pacific
}

John Connell

The people of Tuvalu and Kiribati in the north Pacific, Takuu (Mortlock Islands) and the Carteret Islands in Papua New Guinea, and Australia's Torres Strait Islanders, are now voyaging towards an uncertain future. Rapidly rising sea levels and massive king tides are encroaching on their villages and salt is affecting arable land. The mass migration of entire island communities is imminent.

-Susan Cochrane, "Floating LAND-Rising SEA"

There has been reluctance to leave, especially among older [Carteret] islanders, but after fighting a losing battle against the ocean for more than 20 years (building sea walls and planting mangroves), it appears the islanders have given up hope, resigned to be among the world's first "climate change refugees."

- Johannes Luetz, Planet Prepare

For more than two decades, small Pacific islands, and especially atolls, have been argued to be in the vanguard of climate change and sea-level rise-the "canaries in the coal mine." The most anticipated physical impacts of sea-level rise on islands are coastal erosion, flooding, and salinity intrusion, reducing the resilience of coastal and small island ecosystems. Atolls (and atoll states) are particularly vulnerable to climate change (and to cyclones), having long sinuous coasts and small land areas (Nunn and Kumar 2006). The populations of several islands and island groupsnotably the island state of Tuvalu, the Carteret Islands (Bougainville,

The Contemporary Pacific, Volume 27, Number I, I-36

(C) 2015 by University of Hawai'i Press 
Papua New Guinea [PNG]), and Tegua (Torba, Vanuatu)—have been perceived as the first probable victims of rising seas, so that their inhabitants would become, and in some quarters already are seen to be, the first "environmental" or "climate change refugees" (see, eg, Cochrane 20I0; Luetz 2008). The imminent "fate" of Tuvalu has been widely documented alongside that of other atoll states, especially Kiribati, the Maldives (in the Indian Ocean), and the Marshall Islands (Connell I999; Farbotko 2005, 20I0; Rudiak-Gould 20I3a), to the extent that "Tuvalu's iconic role as 'poster child' for encroaching global disaster is well established" (Chambers and Chambers 2007, 294; see also Goldsmith 2012). The smaller, less accessible Carteret Islands (Kilinailau), Takuu (Bougainville, PNG), and Tegua have largely escaped comparable detailed media coverage but have still been widely seen as early examples of the impact of sea-level rise on small islands, and thus necessitating and experiencing population resettlement (Connell I990, forthcoming; Bohane 2005). Carteret Islanders have typically been described as "the first direct climate change refugees with islands inundated and damaged, gardens and water supplies destroyed by salt water intrusion and evacuation announced in 2005" (Roper 2009, 5). By 2002, the future of nearby Takuu was said to be "increasingly uncertain because of the rising sea levels that continue to erode the shorelines of all its islands... and abscond with meters of beach frontage" (Moyle 2007, 272-273). The island of Tegua "is claimed to be the first in the world to have to move its community because of rising sea levels" (Bohane 2005), and the Tegua Islanders were thus said to be "the first climatic refugees" (Siméoni and Ballu 20I2). Small islands off the west coast of Buka (Bougainville, PNG), such as Petats, have experienced similar changes, with Islanders having "begun to move away from the sea to higher ground" because of encroaching seas (Luetz 2008, I 8). Multiple regional claims have been made to the primacy of climate-change refugees.

Especially but not only in atoll environments, local people and others have pointed to various changes such as erosion, flooding, and contamination of agricultural systems by seawater intrusions that have been widely attributed to global warming and sea-level rise (SLR) (see, eg, Connell 2003; Rudiak-Gould 2009, 20I 2; Kuruppu and Liverman 20I I). Massive public discussion of climate change at international, regional, and local levels has contributed to SLR being the primary explanation for harmful, unusual, or unprecedented environmental changes. Media reports have frequently attributed major environmental problems to climate change and SLR (Connell 2003; Farbotko 2005), notably in Al Gore's documen- 
tary An Inconvenient Truth (Guggenheim 2006), in which Tuvaluans were said to have had "to evacuate to New Zealand." Some academic reports are not averse to similar dramatization, such as SLR having resulted in "the evacuation of some islands in Tuvalu" (Armstrong and Read 2004, I96). Such statements are far from atypical and have resulted in perceptions, first, of environmental changes in small Pacific islands being almost synonymous with SLR and, second, of the necessity (or actuality) of migration as a response. Detaching science and social science from politics, polemics, aspirations, and needs has proved difficult. This article seeks to examine the extent to which climate change has contributed to environmental change and degradation in small island contexts, especially coral atolls, and the extent to which other factors have influenced both environmental change and perceptions of these changes. It is argued that contemporary environmental changes in most islands in the southwest Pacific (figure I) are not necessarily the outcome of SLR but are more likely to be responses to local stresses of various kinds, from geophysical to human, including tectonic movements, cyclones, seawall construction, and sand mining. This is examined below with particular reference to relationships with contemporary Island livelihoods.

\section{SEA-Level Rise}

Sea-level rise has become increasingly evident in the Pacific, with the southwestern Pacific regarded as one of the regions most vulnerable to contemporary and future changes (Nicholls and Cazenave 20I0; Becker et al 20I2; Meyssignac and Cazenave 2OI2). Recent estimates of SLR by the Intergovernmental Panel on Climate Change (IPCC) have indicated a global average of $3 . \mathrm{Imm} /$ year between 1993 and 2009, representing an increase from I.7 mm/year between I950 and 2009, with the eventual outcome of an SLR of between 0.I 8 and 0.59 meters by the end of the twenty-first century. Considerable regional and local variations occur, but relatively few measures (either in time or space) exist for most Island regions. However, contemporary records for the central Pacific suggest that SLRS of around the IPCC estimates are evident (Becker et al 20I2). One study has suggested a rising trend for some Pacific Island states of 3.I mm/year, with Nauru, the Federated States of Micronesia (FSM), Fiji, Tonga, and Kiribati exhibiting even more rapid rises and thus exceeding earlier IPCC predictions (Becker et al 20I2). A further study has pointed to rates as high as $7 \mathrm{~mm}$ /year since 1993 for both the Marshall Islands 


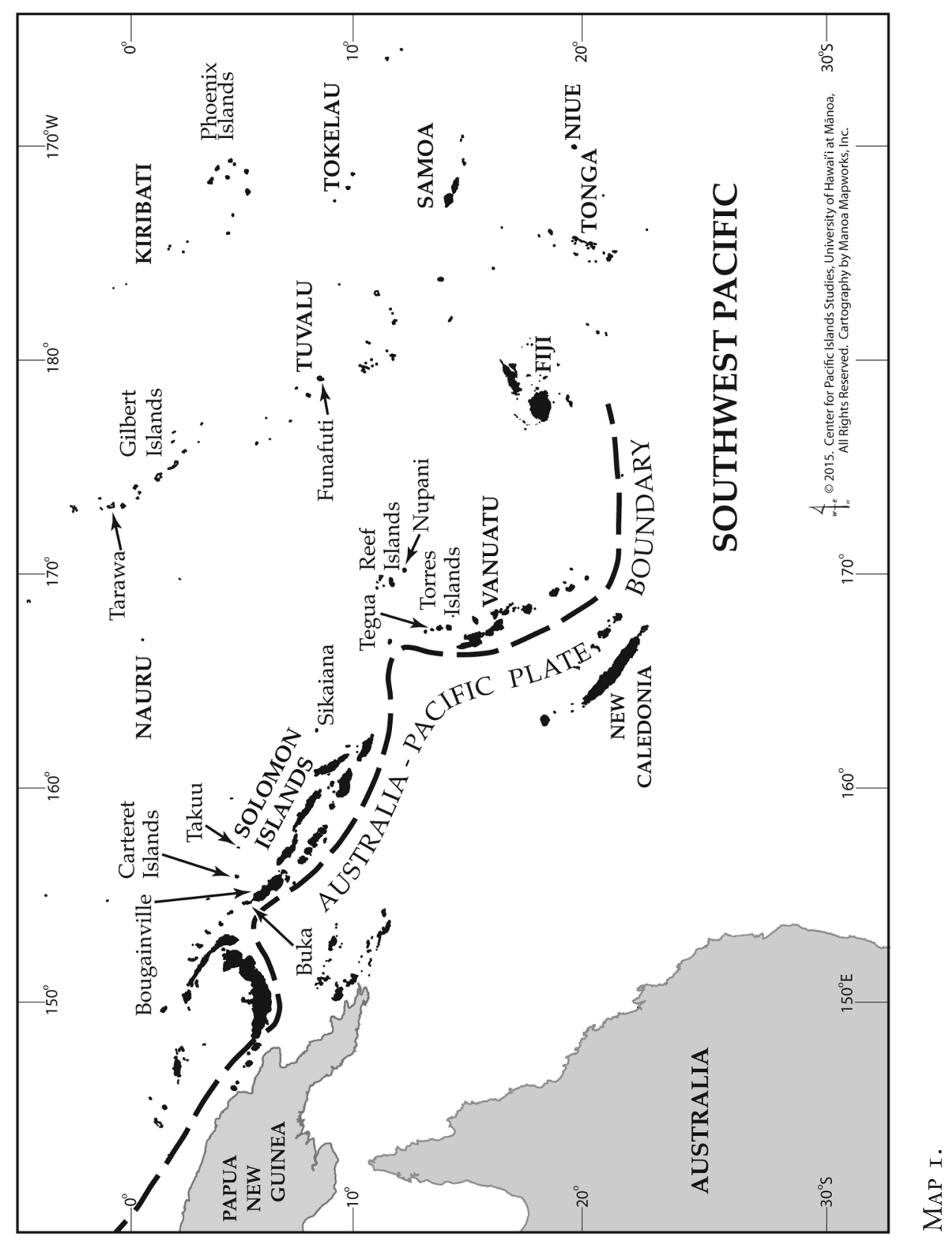


and Papua New Guinea and $5 \mathrm{~mm} /$ year and $\mathrm{I}-4 \mathrm{~mm} /$ year for Tuvalu and Kiribati, respectively (ABM and CSIRO 2OII). Trends and estimates have increased over time.

Specific data exist for some sites. Thus measures of SLR on Abaiang Atoll, Kiribati, using geomorphological techniques, suggest an average rate of SLR ranging from 0.I to $0.2 \mathrm{~mm} /$ year between 1998 and 2008 (Flora, Ely, and Flora 2009) and on Tarawa, Kiribati, of I.4 mm/year between I968 and I998, or I. $8 \mathrm{~mm} /$ year over the thirty-five years since I974 (Biribo and Woodroffe 20I3). Other measurements, however, suggest over $4.3 \mathrm{~mm} /$ year between 2002 and 2009 (Rankey 20II). Lautoka (Fiji) has exhibited an SLR of $4.9 \mathrm{~mm}$ over a twenty-year period. Recent floods in Nadi (Fiji) suggest that SLR is now having a negative impact (Nunn 20I3). Funafuti (Tuvalu) has recently recorded a particularly high rate of $5.1 \mathrm{~mm} /$ year, about three times that of the global mean, whereas in the eastern Pacific rates of between 2.5 and $2.9 \mathrm{~mm} /$ year predominate (Chowdhury, Chu, et al 20I0; Becker et al 20I2). All of these rates are faster than earlier rates, putting increased pressure on Funafuti. Specific measures of SLR are unavailable for any of the Bougainville atolls, Solomon Islands, or most of Vanuatu.

Data exist only for short time periods in several places and are also complicated by El Niño-Southern Oscillation (ENSO) fluctuations, since during La Niña conditions SLr has increased (Hussein, Singh, and Aung 20II; Aung, Singh, and Prasad 2009; Aung, Singh, and Maryam 20II; Chowdhury, Barnston, et al 20I0; Becker et al 2012). Isostatic changes to earth and ocean surfaces further complicate measurement (Woodroffe et al 20I2). Nevertheless, it is reasonable to assume that the rate of SLR is increasing, that it will increase further in the future (Church and White 2006; Horton et al 20I4), and that the western and southwestern Pacific are experiencing more accelerated SLR than the eastern Pacific (Merrifield 20I I; Zhang and Church 20I2). Regional variations, significant discrepancies, and some uncertainty remain in measures of SLR, according to sources and analytical techniques, but a distinct overall upward trend exists throughout the western Pacific.

\section{TeCtONic InSTABILITy}

In the western Pacific, SLR is complicated and compounded by tectonic instability (including both uplift and subsidence) and earthquakes. Thus 
the Torres Islands (Vanuatu), at the convergence of the Australian and Pacific plates, have experienced particularly strong vertical movements while also being earthquake and cyclone prone. Between 1992 and 20I0, SLR around the Torres Islands was nearly $8 \mathrm{~mm} /$ year, significantly above the global and regional average. That exceptional SLR was complicated by movements during and between earthquakes. Between I997 and 2009, the outcome of vertical plate movements was that the island of Tegua subsided by about I I $7 \mathrm{~mm}$ - one of the highest recorded subsidence rates in the world, effectively almost doubling more gradual SLR (Ballu et al 2OII). However, subduction rates vary considerably, even from north to south within Vanuatu, reflecting both tectonic segmentation and the transience of rates measured at particular stages of earthquake cycles (Dickinson 20I3).

Substantial flooding in the Torres Islands, starting in the late I990s, was probably primarily the result of a I997 earthquake (followed by a small tsunami) that accompanied subsidence, while a 2009 earthquake reversed that subsidence, lifting the island by about $200 \mathrm{~mm}$. The I 997 earthquake resulted in subsidence of at least $500 \mathrm{~mm}$ and was probably the main reason for subsequent sea incursions and flooding through progressive erosion of natural barriers. Despite SLR being relatively rapid, the principal cause of observed flooding in Tegua was rapid subsidence, related to plate movements and earthquakes (Ballu et al 20I I; Siméoni and Ballu 20I2). Between 2004 and 2006, flooding resulted in the relocation inland of the village of Lataw-sometimes described as the first migratory response to global warming in the Pacific (Bohane 2005).

Similar explanations account for parallel changes in Vanikoro (Solomon Islands) (Traufetter 20I2), and probably elsewhere in Solomon Islands, both earlier in the Reef Islands-where there had been subsidence "during the last thirty years" on all four of the northern outer islands (Davenport 1975, 68; Birk 2012)—and more recently in the Bougainville islands and atolls, including the Carteret Islands (Duguman 2009), Takuu (Mortlock Islands), the Buka islands, and the Duke of York Islands, all close to the plate boundary. All these islands regularly experience strong earthquakes, which can significantly change sea levels. A single earthquake in Ranongga (Solomon Islands) in 2007 lifted parts of the island by over three meters (McAdoo et al 2008), but subsidence, as in nearby Vella Lavella and Simbo, which subsided almost one meter (Lauer et al 2013), is an alternative outcome. 


\section{El Niño Southern Oscillation}

Globally, three large-scale climate-related changes are simultaneously occurring: a rise in air- and sea-surface temperatures (projected to increase by $2^{\circ} \mathrm{C}$ by 2050); changes in rainfall (with expectations of less frequent but more intense rainfall events, potentially contributing to greater storminess and flooding); and consequent higher sea levels, but with significant regional variations (Lal, Harasawa, and Takahashi 2002; Mimura et al 2007). Each varies regionally in accordance with particular local changes, notably in the El Niño-Southern Oscillation (ENSO), a quasi-periodic climatic pattern that occurs across the Pacific roughly every five years, that changes sea-surface temperatures (warming with El Niño and cooling with La Niña) and air-surface pressures. At the peaks of these cycles, more extreme weather occurs. SLR is complicated further by ENSO events, being affected by large areas of water warming and expanding, or cooling and contracting. Current SLR is a fraction of the sea-level changes that occur as short-term impacts (unusually high tides and storm surges) from ENsOrelated fluctuations.

ENSO fluctuations have occurred for millennia, with a considerable range of outcomes (McGregor et al 2013), and in some places they are linked to local agricultural and ceremonial cycles (Mondragón 2004). In recent decades, the number and intensity of El Niño warming events has increased and the number of La Niña events decreased-a change that may be attributable to global warming. ENso fluctuations have been the most important influence on climate variability in recent decades, but short-term climatic shifts must be differentiated from long-term changes. Particularly high sea levels are recorded during La Niña events, for example, from July 2006 to June 2008 in most of the Pacific (Chowdhury, Barnston, et al 20I0; Siméoni and Ballu 20I2). Various islands, especially atolls, have experienced damage-notably erosion and flooding-caused by both perigean (astronomical) high tides and storm surges associated with particular El Niño conditions. However, fluctuations of island outlines correspond with wind changes associated with ENSO cycles (Solomon and Forbes 1999; Biribo and Woodroffe 2013). Climatic changes, at different scales, are unusually complex, while relatively few accurate measures exist to document the extent and impact of change, both directly and in the outcome of such changes in terms of water availability. How- 
ever, ENSO events have contributed to rainfall patterns becoming more unpredictable, with floods and droughts being accompanying outcomes, while future wet and dry extremes-and hence floods and droughts-are expected to be more intense (Power et al 2013).

Distant-source wind waves, not associated with commonly identified sources such as cyclones or perigean tides, have also been an occasional, and increasingly less rare (Aucan, Hoeke, and Merrifield 20I2), source of inundation of low-lying areas, as occurred in several Pacific Island states in December 2008. Swell generated more than four thousand kilometers from the farthest affected island created considerable damage at a time when regional sea level was already elevated, due to both La Niña conditions and SLR (Hoeke et al 20I3; Rudiak-Gould 20I3a). Atolls from Midway and Wake in the northern Pacific to Takuu were affected. The impact would have been greater had the swells arrived during a peak of spring tides or in stronger La Niña conditions. Flooding in the Marshall Islands in 2013 may have had similar causes.

\section{Cyclones}

Cyclones are frequent in much of the Pacific, other than extremely close to the equator, although cyclonic activity has become more common there (Rasmussen et al 2009). Climate change is expected to result in fewer cyclones but greater individual intensity. Time series data are too limited to give more than localized indications of the extent of any increased periodicity and severity, and in the Pacific region no significant trends in either the number of cyclones or their intensity were evident from I98 I to 2007 (ABM and CSIRO 20II). There have been indications that cyclones are becoming more intense (Webster et al 2005; Elsner, Kossin, and Jagger 2008; Rasmussen et al 2009; Walsh, McInnes, and McBride 20I2), perhaps because of the increased intensity of ENso events. However, the possibility and impact of changing patterns and intensity are uncertain, and, in the Pacific, "owing to their small land masses and widely dispersed nature within a vast expanse of ocean, whether or not individual . . . islands sustain significant damage by the passage of tropical cyclones would seem to be governed largely by chance" (Terry and Etienne 2010, I93). Cyclone frequency and impact are thus highly variable. Tuvalu was hit by an average of three cyclones per decade between the I940s and I970s, but eight occurred in the r980s (Nunn I990), and several have occurred since then but with varied intensity in different parts of the country. 
Cyclones cause environmental changes. Storms may create waves that wash over atolls and contaminate freshwater lenses. A cyclone that swept over Pukapuka (Cook Islands) in 2005 reduced potable lens water supply to brackish water that was unsuitable for drinking for ten months; rainwater tanks and wells were so polluted that freshwater had to be imported, while fresh food supplies were wiped out by incursions of seawater into taro gardens (Terry and Falkland 2010). Similar devastation occurred in the Chuuk atolls (FSM) in 2007 (Hezel 2009), and other, less extensively documented circumstances have affected Funafuti and elsewhere. Yet the storm waves associated with cyclones have positive and negative effects. No other natural process can produce coral debris and transport it from where it is produced by the growth of corals along ocean reef fronts to where it can accumulate in more or less stable landforms. Cyclones are typically destructive in the short term, in relation to property, crops, and freshwater resources, but they can also be agents of island geomorphic enhancement.

\section{Island Shapes and Sizes}

A number of physical influences-long-term SLR, tectonic shifts, ENSO events (resulting in storm surges), cyclones, and distant swells-all contribute to environmental changes on islands. In most contexts, the least significant of these is SLR, while the principal physical influences are recurrent events of various kinds that may not have obviously changed in periodicity in the past century. With the exception of tectonic changes (and especially subsidence), in most circumstances their short-term impacts have been substantial but their long-term influence has usually been slight.

Erosion of islands can lead to a reduction in the size (and water quality) of the freshwater aquifer of the island (Roy and Connell I99I), as on Majuro (Marshall Islands) (Terry and Thaman 2008), or its complete disappearance from smaller islands. Even where islands demonstrate physical resilience, they may be rendered uninhabitable by the diminution of available water resources (Terry and Chui 20I2). However, storms have both constructional and erosional impacts on atolls, depending on the sediment composition of the islands and the orientation of the storm (see, eg, Bayliss-Smith I988; Yates et al 2013). Climate change and sLR are widely anticipated to bring increased rates of erosion and shoreline regression, especially on coral atolls and cays. Erosion has occurred in multiple Pacific island contexts, but there is little evidence of its being consis- 
tently in excess of deposition and accretion in most coastal systems where human impacts are insignificant. By contrast, where human impacts have been considerable, erosion is more likely, especially where coastal vegetation has been removed; hence, erosion occurs particularly in more densely populated urbanized coastal areas (see, eg, Solomon I994; Pierce I999). Erosion is more readily visible there and thus more frequently reported. Deposition may occur elsewhere.

The impact of SLR is greatest for low-lying atoll islands, which have been widely perceived to erode in response, despite accretion usually occurring simultaneously (Woodroffe 2008). Quantitative studies of physical changes in twenty-seven atoll islands in three central Pacific states (FSM, Kiribati, and Tuvalu) over a variable I9-6I-year period (when SLR was measured at $2 \mathrm{~mm} /$ year) show that 86 percent of atoll islands either remained the same size (43 percent) or increased in area (43 percent). Only I4 percent of the islands exhibited a net reduction in area. Despite small overall changes in area, the islands exhibited larger gross changes, expressed as changes in the planform configuration and the position of islands on reef platforms. Many islands therefore increased in area and underwent diverse physical adjustments in response to changing influences, of which SLR was just one. On Funafuti, eleven islands increased in size and five decreased, while four Tarawa islands increased, primarily because of extensive reclamation (Webb and Kench 2010; Biribo and Woodroffe 20I3). In French Polynesia, the atoll of Manuae has decreased in size over a fifty-year period, while Manihi has increased in size, and two other atolls remained more or less stable, with the differences attributed to variability in wave exposure rather than to SLR (Yates et al 20I3; Le Cozannet et al 20I3). On Wotje (Marshall Islands), over a sixty-sevenyear period until 2010, accretion was more prevalent than erosion, but there was a post-2004 shift toward erosion (Ford 20I3). Similarly, three out of four Reef Islands (Solomon Islands) were smaller in 1960 than in $20 \mathrm{IO}$ (Birk 20I2). On Raine Island, a vegetated coral cay in the northern Great Barrier Reef, 34 percent of the coastline experienced net retreat and 44 percent experienced net progradation between I967 and 2007. Despite local concerns that Raine Island was rapidly eroding, net island growth ( 6 percent by area and 4 percent by volume) had occurred. Perceptions of erosion probably reflected large morphological changes arising from seasonal, inter-annual, and inter-decadal patterns of sediment redistribution rather than any net sediment loss (Dawson and Smithers 20I0). One 
Tree Island in the Great Barrier Reef has similarly been stable, with constructional processes on the rubble flats (Shannon et al 20I2). Overall, therefore, atoll islands in the Pacific have grown rather than declined in recent decades.

Local changes on atolls are complex. On Tarawa, between I968 and I998, when the urbanized central atoll of Kiribati experienced what appears to have been a net SLR of I.4 mm/year, shoreline responses varied. Most ocean-facing beaches showed little detectable change, with some showing net erosion and a few showing accretion, but a significant proportion of lagoon beaches also showed accretion. The factors that most influenced change were location and human influence, while substantial fluctuations also occurred in response to El Niño conditions (Biribo and Woodroffe 20I3). The same conjuncture of both accretion and erosion was evident on Maiana and Aranuka atolls (Kiribati) between 2005 and 2009. The greatest erosion was on ocean-facing coasts (where no one lived), where storm and wind impacts were considerable, or on the edges of lagoons near villages that had been most influenced by human activity, notably by the construction of groins and seawalls but also of causeways and boat channels (Gillie I993; Rankey 20I I; Woodroffe and Biribo 20I I). In each of these cases-and in Majuro, where a thirty-five-year record showed that erosion has been greatest in the most urbanized and most modified parts of the atoll (Xue 200I; Ford 20I2; Rudiak-Gould 20I3a), and by the I960s on Nupani (Reef Islands, Solomon Islands) (Davenport I975, 69) - erosion was greatest where human activity was substantial (the construction of causeways, seawalls, vegetation removal, sand and gravel mining, etc). On Abaiang Atoll (Kiribati), areas of the lagoon coast had receded by up to eighty meters in four decades after a channel had been closed, blocking sand transport (Webb 2006). The largely urban concentration of erosion partly explains the widespread media assumptions of generalized erosion following SLR, which have come predominantly from urbanized atolls. Coral islands have otherwise exhibited more resilience and stability than usually assumed under ongoing SLR. Erosion of particular island shorelines takes place in the context of physical adjustments to entire island shorelines, as erosion is more or less balanced by deposition and progradation elsewhere. However, the land deposited is usually coral fragments, as in the Reef Islands (Davenport 1972), and the biological content of the eroded material (notably its soil content) is not replaced by deposition of material of comparable value. 


\section{Human INTERVENTIONS}

Physical changes to atoll topography have both been more evident where human impact has been greatest and most likely to have been observed where population concentrations are greatest (and media interest concentrated). The harmful impacts of SLR have been most frequently reported from Funafuti, the highly urbanized main atoll of Tuvalu, where flooding of the interior of the main island (Fongafale) and the disappearance of the tiny islet of Te Puka Savilivili are widely cited as evidence of the contemporary impact of SLR. The islet's disappearance has been "held up as evidence of the effects of climate change: encroaching tides have erased sandbanks and coconut trees, which die and collapse into the sea when soil becomes too salty" (Williams 200I, 28; quoted in Connell 2003, I00). However, at the end of the nineteenth century, when the geologist Edgeworth David was examining reef changes, the islet had just three coconut trees, compared with thirteen in 1976 (Roger McLean, pers comm, 2002), suggesting that it had gone through cyclical changes and was then growing. In Tarawa, the disappearance of the similar tiny island of Bikeman in Tarawa Lagoon has been likewise incorrectly attributed to SLR (Howorth 2000). Again, the most dramatic changes have been reported for the most urbanized atolls. Much the same appears to be true for Kiribati and the Marshall Islands (Rudiak-Gould 20I2). However, while attribution of environmental damage to global warming and SLR remains primarily an urban phenomenon, coastal erosion and flooding have become more widely apparent.

Each of the key urbanized islands in the three atoll states of Tuvalu, Marshall Islands, and Kiribati-Funafuti, Majuro, and Tarawa-has experienced very substantial post-independence rural-urban migration, resulting in extremely high urban population densities and intense pressure on scarce resources including land, firewood, sand, and gravel. Their human landscapes have changed much more substantially than those of outer islands. Contemporary flooding in Funafuti has been exacerbated by the construction of a permanent airstrip (and its subsequent sealing), which occupies as much as a quarter of the main island; borrow pits (dug during the war for gravel); sand and gravel mining; vegetation removal (mainly for firewood); depletion of the water lens (and resultant compaction); groin and causeway construction; "one-off" reclamation; lagoon eutrophication and the loss of sediment for reef construction; and other 
human-induced changes (Connell 2003; Xue 2005; Woodroffe 2008; Lazrus 2009). Floods in 2006 occurred in parts of the main island lying below high-water level, which had previously been wetlands and were only populated in the I970s during a phase of rapid migration to Funafuti; flooding may also have been affected by excavation of a storm ridge (Yamano et al 2007). In Tarawa and Majuro, erosion and flooding have similarly followed modification of shorelines by reclamation, housing, causeways, and sand and gravel mining, with flooding in Majuro occurring only in recently populated areas (Donner 20I2; Ford 20I2). Sand and gravel mining in lagoons has been particularly damaging, scouring lagoon floors and contributing to coastal erosion, again notably in Funafuti, Tarawa, and Majuro, where demand is greatest (Ambroz 2009; Smith and Collen 2004; McKenzie, Woodruff, and McClennen 2006; Babinard et al 20I4). Even on non-urban atolls such as Vaitupu (Tuvalu), gravel mining has been the primary cause of erosion (Xue 1997). Fewer such changes have occurred on outer islands, where populations have usually declined rather than increased in the post-independence era, hence pressures on the environment have also not increased.

In many atolls, including Woleai and Moch (FSM), Rongelap (Marshall Islands), and elsewhere, Islanders are conscious that erosion is part of a "normal process"-more of the same-and had long taken steps to modify and defend eroded areas and secure land elsewhere, at least as early as the I970s (Bridges and McClatchey 2009; Lipset 20I I; Pam and Henry 20I2; Schneider 20I2). On several Kiribati atolls, many erosion sites had experienced "one or two generations of seawalls" by the I990s (Gillie I993). On Petats, people were aware of "rising water" in the I980s when they began to build seawalls (Luetz 2008, I8). In Tegua, older Islanders recounted how the area that had flooded in the 2000 s had once been a lagoon before reclamation (Siméoni and Ballu 20I2). Similarly, parts of Pororan (Buka) have been reclaimed while, as one Islander pointed out, "on this side, the island is growing, but at other spots, the sea is coming inside" (Schneider 20I2, I I; see also Schneider 20I 2, I 89). The uninhabited interior of Funafuti was subject to flooding in the I890s (Yamano et al 2007). In the Reef Islands, one group of older men suggested that not only was the contemporary erosion rate not unusual but that erosion was often balanced by deposition, with one man claiming that there had been no SLR but that environmental problems were self-inflicted: "We cut trees; we take sand from the beach" (quoted in Birk and Rasmussen 20I4, 9). Cook Islands atoll residents ponder beach erosion and query, "Is this 
climate change-or is it our own work-or both?" (Rubow 2013, 65). In very many islands, there is inherited knowledge of dangers from the ocean. In Tegua, villages and gardens were formerly located on a onehundred-meter platform to avoid tsunamis; villagers were only encouraged to migrate to the coast in colonial times, but the main coastal villages were not established until at least the I930s (Ballu et al 20II). Thus in Funafuti, Tegua, Tarawa, and also Majuro (Spennemann 2006), Islanders have only very recently moved to sites that were avoided in the past and have subsequently proved to be cyclone and flood prone.

It is not surprising that some slow-onset changes such as climate change and SLR have become political issues, because human influences on them occur far from the island Pacific and are the subject of debate and argument and because perceived physical changes that may have alternative explanations can be attributed to climate change and SLR: a "garbage can anarchy" where once separate and complex phenomena have become systematically interrelated (see, eg, Connell 2003; Corlett 2008; Hulme 20I0). Small islands offer sites where the great global narratives of climate change can be comprehended and made tangible and visible, attributed to distant sources, and confirmed by local "green governmentality discourses" based on indigenous knowledge, memory, and eyewitness accounts (see, eg, Farbotko 20I0). News media and occasional nongovernmental organization accounts are replete with romanticized statements such as “[Matsungan] Island chief John Kela doesn't understand the science of climate change. But he sees that the ocean surrounding his island is rising" and "Even as the last veneers of organic matter are pushed out to the ocean, Tobasi [in the largest Carteret island] prays daily for his island. He knows that life on the atoll is coming to an end" (Luetz 2008, I7, 20). Visibilism and populism have triumphed over science (RudiakGould 20I3 b; Swyngedouw 20I0). Single-factor interpretations are limited modes of explanation in the face of evolving scientific knowledge, deny local agency, and invoke powerlessness.

\section{Islands under Pressure}

Small islands and especially atolls have often experienced difficult times. In precolonial times, islands achieved sustainable development partly through extended geographical ties, typified by dispersed clans, and linkages across atolls and between clusters of islands in order to secure social relations and claim and use land elsewhere, as on such densely populated 
islands as Paama (Vanuatu) and Kotu (Tonga) (Perminow I993) or more generally in Micronesian atolls (Petersen 2009). Linkages were often marked by elaborate exchange systems and complex regional and local reciprocal socio-economic-political linkages to ensure sustainability, such as the kula ring in the Trobriand Islands (PNG) and the hierarchical and asymmetrical sawei obligations that tied atoll outer Islanders to the high island of Yap in what is now the Federated States of Micronesia (Alkire I978; Pam and Henry 20I2). Islands were rarely isolated for long, and even the tiny island of Tikopia (Solomon Islands) was part of a Pacific "world system" for most of its three-thousand-year human history (Kirch I986). Survival necessitated external ties. Small islands could not afford to be insular.

Population mobility was inherent to small islands. Without migration, life could be particularly difficult. In extreme form, in small, remote high islands such as Tikopia, achieving sustainability had a high human cost, involving celibacy, infanticide, and other extreme practices to stabilize population size and growth rates; even in contemporary times, island chiefs regulated the population to ensure that it did not pass the number assumed to be sustainable (Kirch I997). On Marshallese atolls, populations were once restricted to two-child families; land was so scarce that only chiefs were buried on land, with commoners buried at sea (Spennemann 2009; Rudiak-Gould 2009). Local and regional contacts sometimes involved feuds, warfare, and violent conflicts over land, resources, and fishing grounds (D'Arcy 2006, 2009). In the more modern era, such practices gave way to dependence on distant governments or migration or both and to a reduction in local sustainability.

By the end of the nineteenth century, in remote atolls like those of Tokelau, "the idea of permanent migration, involving a severance of many ties with the home island and of seeking one's fortune elsewhere, is well established in Tokelau life and thought. For the past 70 years or so it appears to have been accepted ... that some of nearly every group of siblings must tahe 'emigrate' simply because the local resources are seen as insufficient" (Hooper and Huntsman I973, 403-404). Drought in I9I6 resulted in the resettlement of some Kapingamarangi Atoll residents on Pohnpei (Lieber 1977). More recently, migrants left small eastern Fijian islands where their homes were "beautiful, but not places to live" (Bedford I980, 57), while boredom drove migrants from Bikini (Marshall Islands) and Sikaiana (Solomon Islands) (Kiste I974; Donner 2002). The only three Pacific islands depopulated in the twentieth century have been 
small atolls (Connell 20I3a). In Solomon Islands outlier atolls, migration gradually became a household strategy, by which migrants and their families (including those staying behind) diversify sources of incomes in order to minimize risks, such as loss of income and crop failures (Birk and Rasmussen 20I4; Christensen and Gough 20I2). That has only intensified as migration has been prolonged, expectations have risen, and aspirations have increased. In many Pacific islands a culture of migration had become established in which migration was anticipated and normative (Donner 2002; Connell 2008). Small islands became increasingly dependent on remittances.

In postcolonial times, the populations of the main atoll states-Kiribati, Tuvalu, and the Marshall Islands-became greater than at any time in the past, and a new phase of internal migration emphasized urbanization. Internal migration accompanied international migration, as Islanders sought wage employment, preferably with the government, and bureaucracies expanded after independence. The population of Funafuti grew five-fold in three decades after independence, and in Tarawa and Majuro growth was just as rapid. Urban management in atolls has proved exceptionally difficult. In Tarawa, "the impacts of unmanaged urbanisation, a continued crisis of inadequate sanitation, a lack of solid waste disposal controls and ineffective freshwater management offer[ed] . . threats to sustainability" equal to the much-touted issues of climate change and SLR (Storey and Hunter 20I0, I67). Urban atolls were placed under exceptional and unprecedented pressure.

Remittances became even more crucial after the decline and virtual collapse of the copra trade in the I980s and the stagnation of urban employment opportunities, largely ensuring some economic stability on small islands (Chambers and Chambers 200I; Connell 20I3a). By then, Kiribati and Tuvalu had been conceptualized as MIRAB states where international migration generated remittances that were the core of the economy (Bertram and Watters 1985). In Nanumea (Tuvalu), as world copra prices slumped, remittances grew from being about half the island income in the I970s and I980s to constituting some 75 percent in the I990s. In such islands, having large families in the hope that one or more children might eventually migrate and provide remittances became an even more conscious economic strategy (Chambers and Chambers 200I). On Eauripik (FSM), while everyone on the island was "useful," people could become "worthless" if they migrated and sent nothing back (Scourse and Wilkins 
2009). Demand for wages and salaries put intense pressure on urban centers even where international migration was also significant.

\section{Beyond Coral Atolls}

As early as the mid-nineteenth century, population pressures on scarce resources on some of the Gilbert Islands were severe enough for the local people to be described in $\mathrm{I} 865$ by one missionary as "genuine Malthusians" (quoted in Munro and Bedford I980, 3). Although the phrase had no empirical validity, achieving an adequate livelihood was unusually difficult, and warfare was not uncommon. Nukumanu Atoll (PNG) experienced a considerable population reduction in the 1870 s following overpopulation (Bayliss-Smith 1975,3 I 2-3 I3). In several atoll contexts, twentieth-century resettlement has occurred in response to diverse human induced changes. The instigator of the first Gilbertese resettlement in the Phoenix Islands (Kiribati) in the I930s argued that the optimum population density of the Gilbert Islands (the central island chain in Kiribati) had actually been reached by the year I 840 (Maude I968). Nearly a century later, population densities were much higher, food shortages had occurred, poverty was common, and the colonial administration proceeded with resettlement. Two decades later, in the I950s, after recurrent droughts, the Phoenix Islands settlers and others from the Gilbert Islands were relocated in the Solomon Islands. Many Vaitupu (Tuvalu) Islanders resettled on Kioa Island in Fiji around the same time. In Kiribati, in the year of independence, the settlers in the Solomon Islands, once pitied, were now envied: "Settling overseas, beyond the ocean of our islands, is something to be sought after. Why? Because our population is still growing. . . . So now many consider them, the resettled ones, as the fortunate ones and they consider us to be the unfortunate ones" (Schutz and Tenten I979, I27). In the I980s, similar circumstances resulted in the resettlement of I-Kiribati from the main island chain (especially from drought-prone islands such as Tamana) to the thinly populated Line Islands in the east. More recently, various Tuvaluans have settled on Niue. A further similar movement, explicitly justified as a response to "future problems of overcrowding" and following a severe cyclone, was instigated by New Zealand for the Tokelau atolls and was initially envisaged to include the whole population. Government-assisted migration to New Zealand began in I963, resulting in a third of the population migrating, with others migrating 
freely (Wessen et al I992; Huntsman and Kalolo 2007). The atoll population has stabilized and slowly declined as the Tokelauan population has grown in New Zealand.

Similar factors, though less well documented, have stimulated migration from the Carteret Islands and Takuu and have been exacerbated by erosion and flooding. At least since the I960s, the Carteret Islands periodically experienced food shortages of varying severity, associated with steadily growing human and pig populations and the increased conversion of coconuts into copra to generate income. Resettlement to Bougainville was considered as early as the I960s (Mueller I972; Connell I990). Attempts to find appropriate land on nearby Bougainville were thwarted by local landowners, and fewer than ten households have moved (Connell 20I2, forthcoming). In the I950s, when Australian administration officers were similarly concerned about the growing population, overcrowding, and limited garden resources of Takuu, they sent thirty unmarried men to work on plantations elsewhere (Moyle 2007, 25). Such pressures on resources were compounded in 2006 by cyclone damage to the islands, and, in 2008, a series of tidal surges (from wind waves) at the end of a La Niña period washed away kitchens, flooded homes, and destroyed churches. Provincial shipping was unable to resume for several weeks, as hazards emphasized atoll vulnerability and locational disadvantage. However, in 1999, when the provincial government raised the idea of resettlement on Bougainville, it was widely seen as a "fearsome possibility" (Moyle 2007, I6). Both on Takuu and in the Carterets, there was a typical ambivalence between the desire for migration and superior living standards and a preference for holding on to home.

Similar circumstances exist on Nupani. Islanders there "have never been and are not now self-sufficient," so around the early I960s they began to use land on much larger Ndende Island, some forty kilometers away, because of intense pressure on land, to the extent that "every square foot of ground suitable for cultivation has long been planted" (Davenport I969, I73, I74). Reef Islanders were also gradually settling on the neighboring high volcanic island of Tinakula because of land being lost in the I940S and I950s (Davenport I975; Birk 2012). In the I970s, "due to geological changes over the past two decades the food situation has become more critical. . . the eastern edge of Nupani's reef has subsided slightly, probably no more than a few inches [resulting in the erosion of] between one-third and one-half of the islet's best agricultural land" (Davenport I972, I 5; see also Davenport I975, 69). Pororan Islanders have likewise 
colonized the nearby mainland for agriculture (Schneider 20I2). Similar changes have been observed on other islands off the coast of Buka, where four islands (Matsungan, Petats, Torotsian, and Pororan) are said to be shrinking in size, experiencing erosion, and being increasingly affected by more frequent and stronger storm surges and high tides, resulting in the loss of fertile soil and the increased salinity of well water (Luetz 2008). At the turn of the century, the resettlement of Duke of York Islanders was announced since, for their island and "for Takuu, the threat represented by the rising seas is compounded by a violent clash of underwater tectonic plates that triggers periodic earthquakes, tidal waves and volcanic eruptions" (The Independent 2000). But no formal scientific studies appear to have been undertaken (or at least published) on any of the PNG islands and atolls or in the Reef Islands.

The category of "climate-change refugee" (or more generally "environmental refugee"), introduced by well-meaning nongovernmental organizations, has become widely used not just for Pacific Islanders but seemingly globally. It has been resisted in many places, including atoll states, both for its evident denial of sovereignty and independence and because Islanders have no wish to be seen as powerless, passive, or tragic victims, even if that elicits empathy and support elsewhere (McNamara and Gibson 2009; Farbotko 2005; Farbotko and Lazrus 2012; Pam and Henry 20I2). Becoming climate-change refugees has been strongly contested in Tuvalu (Farbotko and Lazrus 200I2) and much disliked elsewhere, as in Kiribati, where the government has sought "migration with dignity." Even where global warming and environmental degradation have been highly politicized, as in Tuvalu, the key objective of migration nonetheless remains one of superior access to employment opportunities and the social and economic benefits derived from them, such as access to housing, health, and education services (Mortreux and Barnett 2009; Paton and FairbairnDunlop 2010; Chevalier 20I0; Shen and Binns 20I2; Shen and Gemenne 20I I; Smith 2013). Yet, in Tuvalu at least, fears of change are such that over a decade ago emigration had already occurred in anticipation of environmental threats (Connell 2003), and some present residents have deliberately prepared for an "out-of-country" option by having particular family members migrate and create a base abroad (Paton and FairbairnDunlop 2010).

For many years, small Pacific islands, especially atolls, have exhibited a considerable degree of poverty (Connell I985, 20I3a), and Islanders have long regarded migration as a means of achieving diversification of 
livelihoods and acquiring remittances. Extreme population pressure on resources was evident on many islands in the nineteenth century (Bayliss-Smith 1975; Green and Green 2007), long before any consideration of environmental change influenced island livelihoods. Islanders as well as colonial and postcolonial authorities often recognized migration as a means of alleviating poverty and food insecurity, and, in Kiribati and Tokelau, formal resettlement schemes were put in place. In many other islands, such as the Bougainville and Solomon Islands atolls and the Reef Islands, Islanders developed their own strategies for migration, colonization, or resettlement elsewhere.

\section{VULNERABLE ISLANDS?}

In every island in the southwestern Pacific, a combination of physical factors (tectonic movements, SLR, ENSO events, cyclones) and human factors (particularly intense where populations are growing) has contributed to environmental change. Disaggregating them is rarely possible. Along the Australia-Pacific plate boundary especially, flooding and coastal erosion have been the outcome of tectonic changes, seismic events, ENSO-related tidal and storm surges, and human modifications rather than of SLR. Variations in SLR have long been influenced by a range of geophysical, gravitational, and oceanographic processes, but diverse measuring techniques (and relatively few of them) and short-term records complicate analysis and explanation. Beyond "visibilism," climate change is unusually difficult to assess because it is nonlinear and cross-scalar and has diverse physical impacts. Yet atolls have exhibited considerable stability over the past half century.

However, rates of SLR are increasing, and greater concentrations of carbon dioxide-ocean acidification-may reduce the calcification of coral reefs and their ability to offer protection, hence threats to atolls are growing. Temperature fluctuations following ENSO events have contributed to reef bleaching, with the consequent reduction in the resilience of coral atolls to other environmental changes and the decline of fisheries potential (Williams et al 2010). Weak evidence suggests that, at least in parts of Solomon Islands, the fruiting patterns of breadfruit have changed (Lal, Kinch, and Wickham 2009). Marine life is moving southward and eastward (Bell et al 2013; Poloczanska et al 2013). This is both a greater threat to island livelihoods than contemporary terrestrial changes-eco- 
nomic or environmental—and a metaphor and forerunner for human migration. The rate of SLR is likely to increase in any future scenario, but the scale and impacts are necessarily uncertain, in part because it is impossible to know how society will evolve in this century. While most atolls are not being eroded overall (though ENSO events, cyclones, and storm surges pose critical problems), physical viability is under increased pressure. It is difficult to attribute specific ecological and environmental changes to climatic change, however much of an "aggravating factor" it appears, even in the western Pacific. Contemporary climate change from global warming is yet to have a more significant impact on environmental change in Pacific Islands than other physical and human factors. That tipping point is yet to be reached. Still, if local and regional factors are presently more significant and "local practices are identified as contributing to ... problems, they cannot absolve external forces from the contribution of global climate change" (Kelman 20IO, 6II).

Environmental changes are evident in most island contexts, but particularly in the two iconic contexts: urbanized atolls (like Funafuti) and islands close to the Australia-Pacific plate (notably the Bougainville atolls). In both contexts, they are frequently attributed to climate change by local people who have been exposed to dominant external discourses of climate-change impacts (Rudiak-Gould 20IO, 20II, 20I3a, 20I3 b; Kuruppu and Liverman 20II; Farbotko and Lazrus 20I2) and by the media. The absence of local scientific studies contributes to this interpretation. Consequently, the more extreme and unusual examples of environmental change that have occurred in urbanized atolls and near the plate boundary have come to represent the norm. Significant physical changes were occurring on coral atolls long before the I990s (and Islanders were conscious of them and taking steps to manage them) when the first inklings of a "greenhouse effect," climate change, and SLR reached the Pacific region. The impact of natural hazards-whether SLR, cyclones, or tidal surges- has been accentuated by intensified population pressure and human modification of coastal land. In most small island contexts, people are more concerned about immediate daily needs than about the longterm implications of climate change and SLR (Storey and Hunter 20IO; Gaillard 2012; Connell 2013 b; Smith 2013). Indeed, in such contexts, as in Kiribati, a focus on climate change can be a "harmful distraction" from meeting present-day livelihood challenges (Gaillard 20I2; Kelman 20I4). A combination of physical and human influences has placed consid- 
erable pressure on small islands and particularly atolls. Achieving sustainable and acceptable livelihoods has become unusually and often increasingly difficult, as aspirations and expectations have increased. For centuries, Islanders have developed extended geographical ties and livelihoods with mobility and migration enabling security. A culture of migration has emerged; transnational corporations of kin have evolved, with "anchor populations" at home, as a form of "homeland security" for possible return migration (Marcus I98I; Rauchholz 20I2), creating multiple versions of the manner in which livelihoods and identity are "determined by both rootedness around the central place and controlled mobility" (Bonnemaison I984, I33). The majority of small islands in the Pacific-where populations were never more than a thousand-probably now have over half their population in urban centers or overseas (Connell 20I3a). Many atolls and all three independent Pacific atoll states have very high population densities and significant concentrations of vulnerable people, and they share common characteristics of small size, limited land and skilled human resources, threatened biodiversity, and scarce financial resources. Economic development is severely constrained.

Small islands and atolls especially are particularly vulnerable to environmental change, partly because they have limited economies, with little flexibility or diversity, that have long resulted in interisland ties and an increased orientation to migration. As contemporary environmental changes have been widely attributed to climate change and SLR, a discourse of climate change-induced migration has become widely accepted in and for atoll environments with the emergence of "climate-change refugees" supposedly imminent (Connell 20I3b). While official state discourses may reject the latter and focus on mitigation and adaptation (McNamara and Gibson 2009), atoll states have simultaneously negotiated migration agreements with metropolitan nations, which have sustained and emphasized Islander aspirations for migration. The conjuncture of enhanced and interlinked socioeconomic and environmental influences on migration, though seemingly intensifying island vulnerability, has created a new discourse of migration and human rights, where local agency is significant and a diasporic future more probable, even if migration is never entirely in circumstances of Islanders' own choosing.

I WOULD LIKE TO THANK Colin Woodroffe and several anonymous referees for the helpful comments on earlier drafts of this paper. 


\section{References}

Авм and CSIro, Australian Bureau of Meteorology and Commonwealth Scientific and Industrial Research Organisation

20I I Climate Change in the Pacific: Scientific Assessment and New Research. Canberra: АВм and CSIRO.

Alkire, William H

I978 Coral Islanders. Arlington Heights, IL: AHM Publishing Corporation.

Ambroz, Angela

2009 Tuvalu Technical Report: A Preliminary Economic Analysis of Extracting Aggregate from the Funafuti Lagoon. SoPAC Project Report 137. Suva: South Pacific Applied Geoscience Commission (SOPAC) Secretariat.

Armstrong, Harvey W, and Robert Read

I998 Trade and Growth in Small States: The Impact of Global Trade Liberalization. World Economy 2I (4): 563-585.

Aucan, J, R Hoeke, and M Merrifield

2012 Wave-Driven Sea Level Anomalies at the Midway Tide Gauge as an Indicator of North Pacific Storminess over the Past 60 Years. Geophysical Research Letters 39, LI7603.

Aung, Than, Awnesh Singh, and Dayang Siti Maryam

20I I Sea Level Changes in the Pacific Region and Impacts of the $2009 \mathrm{El}$ Niño in Fiji Waters. South Pacific Journal of Natural and Applied Sciences 29 (I): 26-30.

Aung, Than, Awnesh Singh, and Uma Prasad

2009 A Study of Sea-Level Changes in the Kiribati Area for the Last I6 Years. Weather 64 (8): 203-206.

Babinard, Julie, Christopher R Bennett, Marea E Hatziolos, Asif Faiz, and Anil Somani

20I4 Sustainably Managing Natural Resources and the Need for Construction Materials in Pacific Island Countries: The Example of South Tarawa, Kiribati. Natural Resources Forum 38 (I): 58-66.

Ballu, Valérie, Marie-Noëlle Bouin, Patricia Siméoni, Wayne C Crawford, Stephane Calmant, Jean-Michel Boré, Tony Kanas, and Bernard Pelletier

20I I Comparing the Role of Absolute Sea-Level Rise and Vertical Tectonic Motions in Coastal Flooding, Torres Islands (Vanuatu). Proceedings of the National Academy of Sciences I08 (32): I3019-13022.

Bayliss-Smith, Tim P

I975 The Central Polynesian Outlier Populations since European Contact. In Pacific Atoll Populations, edited by Vern Carroll, 286-343. Honolulu: University Press of Hawaii. 
I988 The Role of Hurricanes in the Development of Reef Islands, Ontong Java Atoll, Solomon Islands. Geographical Journal I 54 (3): 37739 I.

Becker, M, B Meyssignac, C Letetrel, W Llovel, A Cazenave, and T Delcroix 2012 Sea Level Variations at Tropical Pacific Islands since I950. Global and Planetary Change 80-8I:85-98.

Bedford, Richard D

I980 Demographic Processes in Small Islands: The Case of Internal Migration. In Population-Environment Relations in Tropical Islands: The Case of Eastern Fiji, edited by H C Brookfield, 27-59. Paris: UNEsCo.

Bell, Johann D, Alexandre Ganachaud, Peter C Gehrke, Shane P Griffiths, Alistair J Hobday, Ove Hoegh-Guldberg, Johanna E Johnson, et al

2013 Mixed Responses of Tropical Pacific Fisheries and Aquaculture to Climate Change. Nature Climate Science 3:59 I-599.

Bertram, Geoffrey, and Ray F Watters

I 985 The mirab Economy in South Pacific Microstates. Pacific Viewpoint $26(3): 497-520$.

Biribo, Naomi, and Colin D Woodroffe

2013 Historical Area and Shoreline Change of Reef Islands around Tarawa Atoll, Kiribati. Sustainability Science 8 (3): 345-362.

Birk, Thomas

2012 Relocation of Reef and Atoll Communities as an Adaptation to Climate Change? Learning from Experience in the Solomon Islands. In Climate Change and Human Mobility: Global Challenges to the Social Sciences, edited by K Hastrup and K Olwig, 8I-I09. Cambridge, UK: Cambridge University Press.

Birk, Thomas, and Kjeld Rasmussen

20I4 Migration from Atolls as Climate Change Adaptation: Current Practices, Barriers and Options in Solomon Islands. Natural Resources Forum 38 (I): I-I3.

Bohane, Ben

2005 A Village Flees for Safer Ground. Sydney Morning Herald, 23 December.

Bonnemaison, Joël

I984 The Tree and the Canoe: Roots and Mobility in Vanuatu Societies. Pacific Viewpoint 25 (I): I I7-I 5 I.

Bridges, Kent W, and Will McClatchey

2009 Living on the Margin: Ethnoecological Insights from Marshall Islanders at Rongelap Atoll. Global Environmental Change I9 (2): I 40-I 46.

Chambers, Anne, and Keith Chambers

2007 Five Takes on Climate and Cultural Change in Tuvalu. The Contemporary Pacific 19:294-306. 
Chambers, Keith, and Anne Chambers

$200 \mathrm{I}$ Unity of Heart: Culture and Change in a Polynesian Atoll Society. Prospect Heights, IL: Waveland Press.

Chevalier, Emilie

20 Iо Le climat, facteur d'émigration dans les pays du Sud? Etude des dynamiques spatiales et territoriales des districts d'Eten (Pérou) et de l'atoll de Funafuti (Tuvalu). Mémoire de recherches réalisé en vue de l'obtention du Master GAELE [Geography, Planning, Environment, and Trade Logistics], Université Paris Sorbonne.

Chowdhury, Md Rashed, Anthony G Barnston, Charles "Chip” Guard, Sarah Duncan, Thomas A Schroeder, and P-S Chu

20I0 Sea-Level Variability and Change in the US-Affiliated Pacific Islands: Understanding the High Sea Levels during 2006-2008. Weather 65 (IO): $263-268$.

Chowdhury, Md Rashed, Pao-Shin Chu, Xin Zhao, Thomas A Schroeder, and John J Marra

2010 Sea Level Extremes in the US-Affiliated Pacific Islands-A Coastal Hazard Scenario to Aid in Decision Analyses. Journal of Coastal Conservation I4:53-62.

Christensen, Andreas E, and Katherine Gough

2012 Island Mobilities: Spatial and Social Mobility on Ontong Java, Solomon Islands. Geografisk Tidsskrift (Danish Journal of Geography) I I 2 (I): 52-62.

Church, John A, and Neil J White

2006 A 20 th Century Acceleration in Global Sea-Level Rise. Geophysical Research Letters 33 (I): LOI6O2

Cochrane, Susan

2010 Floating Land-Rising Sea: Arts and Minds on Climate Change. LINQ 37:93-IO3.

Connell, John

I990 The Carteret Islands: Precedents of the Greenhouse Effect. Geography 75 (2): I 52-I 54 .

I985 Islands on the Poverty Line. Pacific Viewpoint 26 (2): 463-473.

I999 Environmental Change, Economic Development, and Emigration in Tuvalu. Pacific Studies 22 (I): I-20.

2003 Losing Ground? Tuvalu, the Greenhouse Effect and the Garbage Can. Asia Pacific Viewpoint 44 (2): 89-107.

2008 Niue: Embracing a Culture of Migration. Journal of Ethnic and Migration Studies 34 (6): IO2 I-I040.

2012 Population Resettlement in the Pacific: Lessons from a Hazardous History? Australian Geographer 43 (2): I 27-I42.

$2013 \mathrm{a}$ Islands at Risk? Environments, Economies and Contemporary Change. Cheltenham, uk: Edward Elgar. 
20I $3 \mathrm{~b}$ Soothing Breezes? Island Perspectives on Climate Change and Migration. Australian Geographer 44 (4): 465-480.

forthcoming Nothing There Atoll? Farewell to the Carteret Islands. In Appropriating Climate Change: Pacific Reception of a Scientific Prophecy, edited by Anthony Crook and Peter Rudiak-Gould. WarCorlett, David saw: De Gruyter Open (2015).

2008 Stormy Weather: The Challenge of Climate Change and Displacement. Sydney: University of New South Wales Press.

D'Arcy, Paul

2006 The People of the Sea: Environment, Identity, and History in Oceania. Honolulu: University of Hawai'i Press.

2009 Variable Rights and Diminishing Control: The Evolution of Indigenous Maritime Sovereignty in Oceania. In Water, Sovereignty and Borders in Asia and Oceania, edited by Devleena Ghosh, Heather Goodall, and Stephanie Hemelryk Donald, 20-37. London: Routledge.

Davenport, William

I969 Social Organization Notes on the Northern Santa Cruz Islands: The Main Reef Islands. Baessler-Archiv I 7: I 5 I-243.

I972 Social Organization Notes on the Northern Santa Cruz Islands: The Outer Reef Islands. Baessler-Archiv 20: I I-95.

I975 The Population of the Outer Reef Islands, British Solomon Islands Protectorate. In Pacific Atoll Populations, edited by Vern Carroll, 64-I I6. Honolulu: University Press of Hawaii.

Dawson, John L, and Scott Smithers

2010 Shoreline and Beach Volume Change between I967 and 2007 at Raine Island, Great Barrier Reef, Australia. Global and Planetary Change 72 (3): I4 I-I 54 .

Dickinson, William R

20I3 Control of Paleoshorelines by Trench Forebulge Uplift, Loyalty Islands. Quaternary Research 80 (I): I $25-\mathrm{I} 37$.

Donner, Simon

2012 Sea Level Rise and the Ongoing Battle of Tarawa. Eos 93 (I7): I69I7I.

Donner, William

2002 Rice and Tea, Fish and Taro: Sikaiana Migration to Honiara. Pacific Studies 25 (I-2): 23-44.

Duguman, John

2009 The Relocation of the Carteret Islanders, Autonomous Region of Bougainville, Papua New Guinea. unesco/APMrn, Port Moresby, mimeo. Copy in author's files. 
Elsner, James B, James P Kossin, and Thomas H Jagger

2008 The Increasing Intensity of the Strongest Tropical Cyclones. Nature 455:92-95.

Farbotko, Carol

2005 Tuvalu and Climate Change: Constructions of Environmental Displacement in the Sydney Morning Herald. Geografiska Annaler, Series B, Human Geography 87 (4): 279-293.

2010 Wishful Sinking: Disappearing Islands, Climate Refugees and Cosmopolitan Experimentation. Asia Pacific Viewpoint 5I (I): 47-60.

Farbotko, Carol, and Heather Lazrus

2012 The First Climate Refugees? Contesting Global Narratives of Climate Change in Tuvalu. Global Environmental Change 22 (2): 382-390.

Flora, Charles, Philip Ely, and Amelia Flora

2009 Microatoll Edge to ENSO Annulus Growth Suggests Sea Level Change. Atoll Research Bulletin 57 I:I-IO.

Ford, Murray

20I2 Shoreline Changes on an Urban Atoll in the Central Pacific Ocean: Majuro Atoll, Marshall Islands. Journal of Coastal Research 28 (I): I I-22.

20I3 Shoreline Changes Interpreted from Multi-temporal Aerial Photographs and High Resolution Satellite Images: Wotje Atoll, Marshal Islands. Remote Sensing of Environment I3 5:I30-I40.

Gaillard, Jean-Christophe 20I2 The Climate Gap. Climate and Development 4 (4): 26I-264.

Gillie, Richard D

I993 Coastal Erosion Problems in the Gilbert Islands Group, Republic of Kiribati. sopac Technical Report 167. Suva: SOPAC.

Goldsmith, Michael

2012 The Colonial and Postcolonial Roots of Ethnonationalism in Tuvalu. Journal of the Polynesian Society I2I (I): I 29-I 50.

Green, Valerie J, and Roger C Green

2007 An Accent on Atolls in Approaches to Population Histories of Remote Oceania. In The Growth and Collapse of Pacific Island Societies, edited by Patrick V Kirch and Jean-Louis Rallu, 232-256. Honolulu: University of Hawai'i Press.

Guggenheim, Davis, director

2006 An Inconvenient Truth. Documentary film. Distributed by Paramount Classics.

Hezel, F X

2009 High Water in the Low Atolls. Micronesian Counselor 76. Pohnpei: Micronesian Seminar. 
Hoeke, Ron K, Kathleen L McInnes, Jens C Kruger, Rebecca J McNaught, John R Hunter, and Scott G Smithers

2013 Widespread Inundation of Pacific Islands Triggered by DistantSource Wind-Waves. Global and Planetary Change Io8:128-138. Hooper, Antony, and Judith Huntsman

I973 A Demographic History of the Tokelau Islands. Journal of the Polynesian Society 82 (4): 366-4 I I.

Horton, Benjamin P, Stefan Rahmstorf, Simon E Engelhart, and Andrew C Kemp 2014 Expert Assessment of Sea-Level rise by AD 2100 and AD 2300. Quaternary Science Reviews 84:I-6.

Howorth, Russell

2000 Waves and Vanishing Islands. Islands Business 26 (June): 48-49.

Hulme, Mike

2010 Cosmopolitan Climates: Hybridity, Foresight and Meaning. Theory, Culture and Society 27 (2-3): 267-276.

Huntsman, Judith, and Kelihiano Kalolo

2007 The Future of Tokelau. Auckland: Auckland University Press.

Hussein, Muhammad Ali, Aunesh Singh, and Than Aung

20 I Rise and Fall of Sea Level in Nauru Area over a Nodal Cycle. South Pacific Journal of Natural and Applied Sciences 28:63-68.

The Independent (UK)

2000 I,000 Flee as Sea Begins to Swallow up Pacific Islands. 29 November.

Kelman, Ilan

2010 Hearing Local Voices from Small Island Developing States for Climate Change. Local Environment I 5 (7): 605-6I9.

20I4 No Change from Climate Change: Vulnerability and Small Island Developing States. The Geographical Journal I 80 (2): I 20-I 29.

Kirch, Patrick V

I986 Exchange Systems and Inter-island Contact in the Transformation of an Island Society: The Tikopia Case. In Island Societies, edited by Patrick V Kirch, 33-4I. Cambridge, UK: Cambridge University Press.

I997 Microcosmic Histories: Island Perspectives on "Global” Change. American Anthropologist 99 (I): 30-42.

Kiste, Robert

I974 The Bikinians: A Study in Forced Migration. Menlo Park, CA: Cummings.

Kuruppu, Natasha, and Diana Liverman

20I I Mental Preparation for Climate Adaptation: The Role of Cognition and Culture in Enhancing Adaptive Capacity of Water Management in Kiribati. Global Environmental Change 21:657-669. 
Lal, Murari, Hideo Harasawa, and Kiyoshi Takahashi 2002 Future Climate Change and Its Impacts over Small Island States. Climate Research I9:179-I92.

Lal, Padma Narsey, Jeff Kinch, and Frank Wickham 2009 Review of Economic and Livelihood Impact Assessments of, and Adaptation to, Climate Change in Melanesia. Apia: Secretariat of the Pacific Region Environment Programme.

Lauer, Matthew, Simon Albert, Shankar Aswani, Benjamin Halpern, Luke Campanella, and Douglas La Rose

20I3 Globalization, Pacific Islands and the Paradox of Resilience. Global Environmental Change 23:40-50.

Lazrus, Heather

2009 The Governance of Vulnerability: Climate Change and Agency in Tuvalu, South Pacific. In Anthropology and Climate Change, edited by Susan A Crate and Mark Nuttall, 240-249. Walnut Creek, CA: Left Coast Press.

Le Cozannet, Gonéri, Manuel Garcin, Lise Petitjean, Anny Cazenave, Mélanie Becker, Benoit Meyssignac, Patrice Walker, et al

20I3 Exploring the Relation between Sea Level Rise and Shoreline Erosion Using Sea Level Reconstructions: An Example in French Polynesia. Special issue of Journal of Coastal Research 65:2137$2 \mathrm{I} 42$.

Lieber, Michael D

I977 The Processes of Change in Two Kapingamarangi Communities. In Exiles and Migrants in Oceania, edited by Michael D Lieber, 35-66. Honolulu: University Press of Hawaii.

Lipset, David

20I I The Tides: Masculinity and Climate Change in Coastal Papua New Guinea. Journal of the Royal Anthropological Institute I7 (I): 20-43.

Luetz, Johannes

2008 Planet Prepare: Preparing Coastal Communities in Asia for Future Catastrophes. Bangkok: World Vision International.

Marcus, George E

I98 I Power on the Extreme Periphery: The Perspective of Tongan Elites in the Modern World System. Pacific Viewpoint 22 (I): 48-64.

Maude, Harry E I968 Of Islands and Men. Melbourne: Oxford University Press.

McAdoo, Brian G, Hermann Fritz, Kelly L Jackson, Nikos Kalligeris, Jens Kruger, Michael Bonté-Grapentin, Andrew Moore, et al 2008 Solomon Islands Tsunami, One Year Later. Eos 89 (I 8): I69-I70. 
McGregor, H V, M J Fischer, M K Gagan, D Fink, S J Phipps, H Wong, and C D Woodroffe

2013 A Weak El Niño/Southern Oscillation with Delayed Seasonal Growth around 4,300 Years Ago. Nature Geoscience 6 (I I): 949-953.

McKenzie, Emily, Alison Woodruff, and Caleb McClennen

2006 Economic Assessment of the True Costs of Aggregate Mining in Majuro Atoll, Republic of the Marshall Islands. SOPAC Technical Report 383. Suva: SOPAC.

McNamara, Karen Elizabeth, and Chris Gibson

2009 "We Do Not Want to Leave Our Land": Pacific Ambassadors at the United Nations Resist the Category of "Climate Refugees." Geoforum 40:475-483.

Merrifield, Mark A

20II A Shift in Western Tropical Pacific Sea Level Trends during the I990s. Journal of Climate 24 (I 5): 4I 26-4 I38.

Meyssignac, Benoit, and Anny Cazenave

2012 Sea Level: A Review of Present-Day and Recent-Past Changes and Variability. Journal of Geodynamics 58:96-109.

Mimura, Nobuo, Leonard Nurse, Roger McLean, John Agard, Lino Briguglio, Penehuro Lefale, Rolph Payet, and Graham Sem

2007 Small Islands. In Climate Change 2007: Impacts Adaptation and Vulnerability; Contribution of Working Group II to the Fourth Assessment Report of the Intergovernmental Panel on Climate Change, edited by Martin Parry, Osvaldo Canziani, Jean Palutikof, Paul van der Linden, and Clair Hanson, 687-7 I6. Cambridge, uk: Cambridge University Press.

Mondragón, Carlos

2004 Of Winds, Worms and Mana: The Traditional Calendar of the Torres Islands, Vanuatu. Oceania 74:289-308.

Mortreux, Colette, and Jon Barnett

2009 Climate Change, Migration and Adaptation in Funafuti, Tuvalu. Global Environmental Change I9:105-II2.

Moyle, Richard

2007 Songs from the Second Float: A Musical Ethnography of Takū Atoll, Papua New Guinea. Pacific Islands Monograph Series 2 I. Honolulu: Center for Pacific Islands Studies, University of Hawai'i, and University of Hawai'i Press.

Mueller, A

I972 Notes on the Tulun or Carteret Islands. Journal of the Papua New Guinea Society 6 (I): 77-83.

Munro, Doug, and Richard Bedford

I980 Historical Background. In A Report on the Results of the Census of Tuvalu, I-I3. Funafuti: Government of Tuvalu. 
Nicholls, Robert J, and Anny Cazenave

2010 Sea-Level Rise and Its Impact on Coastal Zones. Science 328 (5985): I 5 I $7-$ I 520.

Nunn, Patrick D

I990 Oceanic Islands. Oxford: Blackwell.

2013 The End of the Pacific? Effects of Sea Level Rise on Pacific Island Livelihoods. Singapore Journal of Tropical Geography 34 (2): I43I7I.

Nunn, Patrick D, and Roslyn Kumar

2006 Coastal Evolution in the Asia-Pacific Region. In Global Change and Integrated Coastal Management: The Asia-Pacific Region, edited by Nick Harvey, 93-I I6. Berlin: Springer.

Pam, Christine, and Rosita Henry

2012 Risky Places: Climate Change Discourse and the Transformation of Place on Moch (Federated States of Micronesia). Shima 6 (I): 30-46.

Paton, Kathryn, and Peggy Fairbairn-Dunlop

20 Iо Listening to Local Voices: Tuvaluans Respond to Climate Change. Local Environment I 5:687-698.

Perminow, Alex

I993 Between the Forest and the Big Lagoon: The Microeconomy of Kotu Island in the Kingdom of Tonga. Pacific Viewpoint 34:I79-I92.

Petersen, Glenn

2009 Traditional Micronesian Societies. Honolulu: University of Hawai'i Press.

Pierce, $\mathrm{P}$

I999 Changing Coastline at Mele Beach, Vanuatu. Geography 84:I49I 63 .

Poloczanska, Elvira S, Christopher J Brown, William J Sydeman, Wolfgang Kiessling, David S Schoeman, Pippa J Moore, Keith Brander, et al

2013 Global Imprint of Climate Change on Marine Life. Nature Climate Change 3:919-925.

Power, Scott, François Delage, Christine Chung, Greg Kociuba, and Kevin Keay 2013 Robust Twenty-First-Century Projections of El Niño and Related Precipitation Variability. Nature 502:54I-545.

Rankey, Eugene C

20I I Nature and Stability of Atoll Island Shorelines: Gilbert Island Chain,

Kiribati, Equatorial Pacific. Sedimentology 58 (7): I 83 I-I 859.

Rasmussen, Kjeld, Wilhelm May, Thomas Birk, Melchior Mataki, Ole Mertz, and Douglas Yee

2009 Climate Change on Three Polynesian Outliers in the Solomon Islands: Impacts, Vulnerability and Adaptation. Geografisk Tidsskrift Io9 (I): I-I3. 
Rauchholz, Manuel

2012 Discourses on Chuukese Customary Adoption, Migration, and the Laws of State(s). Pacific Studies 35 (I-2): I I9-I43.

Roper, Tom

2009 Implications for the Pacific. Tiempo 70:3-7.

Roy, Peter, and John Connell

I99I Climatic Change and the Future of Atoll States. Journal of Coastal

Rubow, Cecilie Research 7 (4): 1057-1075.

20I3 Enacting Cyclones: The Mixed Response to Climate Change in the Cook Islands. In The Social Life of Climate Change Models: Anticipating Nature, edited by Kirsten Hastrup and Martin Skrydstrup, 57-76. New York: Routledge.

Rudiak-Gould, Peter

2009 Surviving Paradise: One Year on a Disappearing Island. New York: Sterling.

2010 The Fallen Palm: Climate Change and Culture Change in the Marshall Islands. Saarbrücken: VDM Verlag.

20I I Climate Change and Anthropology. Anthropology Today 27 (2): 9-I 2.

2012 Promiscuous Corroboration and Climate Change Translation: A Case Study from the Marshall Islands. Global Environmental Change 22 (I): 46-54.

2013a Climate Change and Tradition in a Small Island State: The Rising Tide. New York: Routledge.

2013b "We Have Seen It with Our Own Eyes": Why We Disagree about Climate Change Visibility. Weather, Climate and Society 5 (2): I 20I32.

Schneider, Katharina

2012 Saltwater Sociality: A Melanesian Island Ethnography. New York: Berghahn.

Schutz, Betty, and Rumaroti Tenten

I979 Adjustment: Problems of Growth and Change, I892 to I944. In Kiribati: Aspects of History, by Alaima Talu et al, I06-1 27. Suva: Institute of Pacific Studies.

Scourse, Andrew, and Corinne Wilkins

2009 Impacts of Modernisation on Traditional Food Resource Management and Food Security on Eauripik Atoll, Federated States of Micronesia. Food Security I:I69-176.

Shannon, Amelia M, Hannah E Power, Jody M Webster, and Ana Vila-Concejo

2012 Evolution of Coral Rubble Deposits on a Reef Platform as Detected by Remote Sensing. Remote Sensing 5 (I): I-I 8. 
Shen, Shawn, and Tony Binns

20I2 Pathways, Motivations and Challenges: Contemporary Tuvaluan Migration to New Zealand. GeoJournal 77:63-82.

Shen, Shawn, and François Gemenne

20I I Contrasted Views on Environmental Change and Migration: The Case of Tuvaluan Migration to New Zealand. International Migration 49 (SI): 224-242.

Siméoni, Patricia, and Valérie Ballu

2012 Le mythe des premiers réfugiés climatiques: Mouvements de populations et changements environnementaux aux îles Torres (Vanuatu). Annales de Géographie 685:219-24I.

Smith, Robert, and John Collen

2004 Sand and Gravel Resources of Majuro Atoll, Marshall Islands. SOPAC Technical Report 360. Suva: SOPAC.

Smith, Roy

20I3 Should They Stay or Should They Go? A Discourse Analysis of Factors Influencing Relocation Decisions among the Outer Islands of Tuvalu and Kiribati. Journal of New Zealand and Pacific Studies I (I): 23-39.

Solomon, Steve M

I994 A Review of Coastal Processes and Analysis of Historical Coastal Change in the Vicinity of Apia, Western Samoa. Sopac Technical Report 208. Suva: SOPAC.

Solomon, Steven M, and Donald L Forbes

I999 Coastal Hazards and Associated Management Issues on South Pacific Islands. Ocean and Coastal Management 42 (6-7): 523-554.

Spennemann, Dirk H R

2006 Nontraditional Settlement Patterns and Typhoon Hazard on Contemporary Majuro Atoll, Republic of the Marshall Islands. Environmental Management 20:337-348.

2009 Water Futures and Their Influence on Sovereignty in the Marshall Islands. In Water, Sovereignty and Borders in Asia and Oceania, edited by Devleena Ghosh, Heather Goodall, and Stephanie Hemelryk Donald, 50-7 I. London: Routledge.

Storey, Donovan, and Shawn Hunter

20Iо Kiribati: An Environmental "Perfect Storm." Australian Geographer 4I (2): I67-I8I.

Swyngedouw, Erik

20I0 Apocalypse Forever? Post-political Populism and the Spectre of Climate Change. Theory, Culture and Society 27 (2-3): 2I3-232.

Terry, James P, and Ting Fong May Chui

2OI2 Evaluating the Fate of Freshwater Lenses on Atoll Islands after 
Eustatic Sea-Level Rise and Cyclone-Driven Inundation: A Modelling Approach. Global and Planetary Change 88-89:76-84.

Terry, James P, and Samuel Etienne

2010 Recent Heightened Tropical Cyclone Activity East of $180^{\circ}$ in the South Pacific. Weather 65 (7): 193-I95.

Terry, James P, and Anthony C Falkland

2010 Responses of Atoll Freshwater Lenses to Storm-Surge Overwash in the Northern Cook Islands. Hydrogeology Journal I 8 (3): 749-759.

Terry, James P, and Randolph R Thaman

2008 Physical Geography of Majuro and the Marshall Islands. In The Marshall Islands: Environment, History and Society in the Atolls, edited by James P Terry and Frank R Thomas, I-22. Suva: Faculty of Oceans and Islands, University of the South Pacific.

Traufetter, Gerald

2012 Climate Change or Tectonic Shifts? The Mystery of the Sinking South Pacific Islands. Der Spiegel 24, I I June.

Walsh, Kevin J, Kathleen L McInnes, and John L McBride

2OI 2 Climate Change Impacts on Tropical Cyclones and Extreme Sea Levels in the South Pacific: A Regional Assessment. Global and Plan-

Webb, Arthur etary Change 80:I49-164.

2006 Analysis of Coastal Change and Erosion: Tebunginako Village, Abaiang, Kiribati. EU EDF 8/9 - sopaC Project Report 53. Suva: SOPAC.

Webb, Arthur P, and Paul S Kench

2010 The Dynamic Response of Reef Islands to Sea-Level Rise: Evidence from Multi-decadal Analysis of Island Change in the Central Pacific. Global and Planetary Change 72:234-246.

Webster, P J, G J Holland, J A Curry, and H-R Chang

2005 Changes in Tropical Cyclone Number, Duration, and Intensity in a Warming Environment. Science 309 (5742): I 844-I 846.

Wessen, Albert F, Antony Hooper, Judith Huntsman, Ian A M Prior, and Clare E Salmond

I992 Migration and Health in a Small Society: The Case of Tokelau. Oxford: Clarendon Press.

Williams, David

200I Sinking Feeling. Time Magazine, 20 August.

Williams, Gareth J, Ingrid S Knapp, James E Maragos, and Simon K Davy

20I0 Modeling Patterns of Coral Bleaching at a Remote Central Pacific Atoll. Marine Pollution Bulletin 60 (9): I467-I 476.

Woodroffe, Colin D

2008 Reef-Island Topography and the Vulnerability of Atolls to Sea-Level Rise. Global and Planetary Change 62 (I-2): 77-96. 
Woodroffe, Colin D, and Naomi Biribo

20 I A Atolls. In Encyclopedia of Modern Coral Reefs, edited by David Hopley, 5 I-7I. Dordrecht: Springer.

Woodroffe, Colin D, Helen V McGregor, Kurt Lambeck, Scott G Smithers, and David Fink

20 I2 Mid-Pacific Microatolls Record Sea-Level Stability over the Past 5000 yr. Geology 40 (IO): 95 I-954.

Xue, Chunting

I997 Coastal Erosion and Management of Vaitupu Island, Tuvalu. SOPAC Technical Report 243. Suva: SOPAC.

200 I Coastal Erosion and Management of Majuro Atoll, Marshall Islands. Journal of Coastal Research 17:909-91 8.

2005 Causes of Land Loss in Tuvalu, a Small Island Nation in the Pacific. Journal of Ocean University of China 4 (2): I I 5-I 23.

Yamano, Hiroya, Hajime Kayanne, Toru Yamaguchi, Yuji Kuwahara, Hiromune Yokoki, Hiroto Shimazaki, and Masashi Chikamori

2007 Atoll Island Vulnerability to Flooding and Inundation Revealed by Historical Reconstruction: Fongafale Islet, Funafuti Atoll, Tuvalu. Global and Planetary Change 57 (3-4): 407-4I6.

Yates, Marissa L, Gonéri Le Cozannet, Manuel Garcin, Emilie Salaï, and Patrice Walker

20I3 Multidecadal Atoll Shoreline Change on Manihi and Manuae, French Polynesia. Journal of Coastal Research 29 (4): 870-882.

Zhang, Xuebin, and John A Church

20I2 Sea Level Trends, Interannual and Decadal Variability in the Pacific Ocean. Geophysical Research Letters 39 (2I): L2I70I.

\section{Abstract}

Small Pacific islands, especially atolls, have been widely argued to be in the forefront of climate change. Recent degradation of island environments has primarily been attributed to the impact of sea-level rise. However, physical changes to several small islands can be linked to a range of physical influences and to human modification. La Niña events, cyclones, and wind waves have caused localized flooding and storm damage. Most atoll islands have not significantly changed in size, as deposition balances erosion. Many islands have experienced broadly similar environmental problems in earlier times, at different scales, and over different time periods, now accentuated by human pressures on scarce land areas and resources. Local human factors (including construction and mining), tectonic subsidence, and La Niña events have created some iconic sites that have become sym- 
bols of sea-level rise, sometimes erroneously attributed solely to global warming. Limited economic prospects in most small islands, rising expectations, and growing populations have contributed to a culture of migration, marked by international migration and urbanization, that has diversified impoverished livelihoods, extended island geographies, and resulted in accentuated population concentrations. Contemporary climate change exacerbates present environmental changes, stimulates further migration, and points to diasporic futures.

KEYWORDS: atolls, climate change, sea level, tectonics, urbanization, migration 